\title{
Multidetector computed tomography diagnosis of ileal and antropyloric gallstone ileus
}

\author{
İleum ve antropilorik yerleşimli safra taşı ileusunun \\ çok kesitli bilgisayarlı tomografi ile tanısı
}

\author{
Naime ALTINKAYA, ${ }^{1}$ Zafer KOÇ, ${ }^{1}$ Özlem ALKAN, ${ }^{1}$ Şenay DEMİR, ${ }^{1}$ Sedat BELLİ ${ }^{2}$
}

\begin{abstract}
Gallstone-induced ileus is a rare complication of cholelithiasis, and gastric outlet obstruction is even rarer. We describe the multidetector computed tomographic diagnosis of small bowel obstruction resulting from a gallstone impacted in the distal ileum and of gastric outlet obstruction from a gallstone impacted in the pyloric antrum (Bouveret syndrome).
\end{abstract}

Key Words: Bouveret syndrome; gallstone ileus; multidetector computed tomography.
Safra taşı ileusu kolelithiasisin nadir görülen bir komplikasyonu olmakla birlikte mide çıkış yolu tıkanıklığı çok daha nadir görülür. Bu yazıda, distal ileuma impakte safra taşı sonucu gelişen ince bağırsak tıkanıklığı ve pilorik antruma impakte safra taşı sonucu gelişen mide çıkış yolu tıkanıklığının (Bouveret sendromu) çok kesitli bilgisayarlı tomografi bulgularını tanımladık.

Anahtar Sözcükler: Bouveret sendromu; safra taşı ileusu; çok kesitli bilgisayarlı tomografi.
Gallstone-induced ileus is a rare complication of cholelithiasis, and gastric outlet obstruction is even rarer. ${ }^{[1]}$ The morbidity and mortality of gallstone ileus remain very high, partly because of misdiagnosis and delayed diagnosis. Therefore, early diagnosis and prompt treatment could reduce the mortality. ${ }^{[2]}$ Small bowel ileus caused by gallstones has become more commonly encountered with the increased use of computed tomography (CT). ${ }^{[3]}$

We report two cases in which gallstone ileus was initially diagnosed using multidetector computed tomography (MDCT).

\section{CASE REPORTS}

Case 1- A 58-year-old male was admitted to the emergency department with a one-week history of abdominal pain, constipation, flatus, defecation, intermittent nausea, and vomiting. His vital signs were stable, and the physical examination disclosed only mild tenderness in the right upper quadrant. The patient was admitted from the emergency department for evaluation of small bowel obstruction. Positive laboratory values included an elevated alkaline phosphatase of $326 \mathrm{U} / \mathrm{L}$ and alanine aminotransferase of $206 \mathrm{U} / \mathrm{L}$.
An erect abdominal plain film showed mildly dilated bowel loops.

Computed tomography (CT) showed the classic triad of findings in gallstone ileus: dilated loops of the small bowel, air in the gallbladder, and an ectopic stone in the ileum. The gallbladder and duodenal walls were thickened, and a cholecystoduodenal fistula was noted (Fig. 1).

During surgery, a $3-\mathrm{cm}$ gallstone was extracted via an enterotomy, a cholecystectomy was performed, and the wall of the duodenum was repaired.

Case 2- A 70-year-old male with a history of diabetes mellitus presented to the emergency department with a one-week history of abdominal pain, intermittent nausea and vomiting. The physical examination disclosed tenderness in the right upper quadrant. Pertinent positive laboratory values included an elevated white blood cell count at $15 \times 10^{9} / \mathrm{L}$ and alkaline phosphatase of $167 \mathrm{U} / \mathrm{L}$.

Right upper quadrant sonography failed to show the gallbladder because of overlying gas. CT of the abdomen showed air and oral contrast material in a partially contracted gallbladder with a thickened, en- 

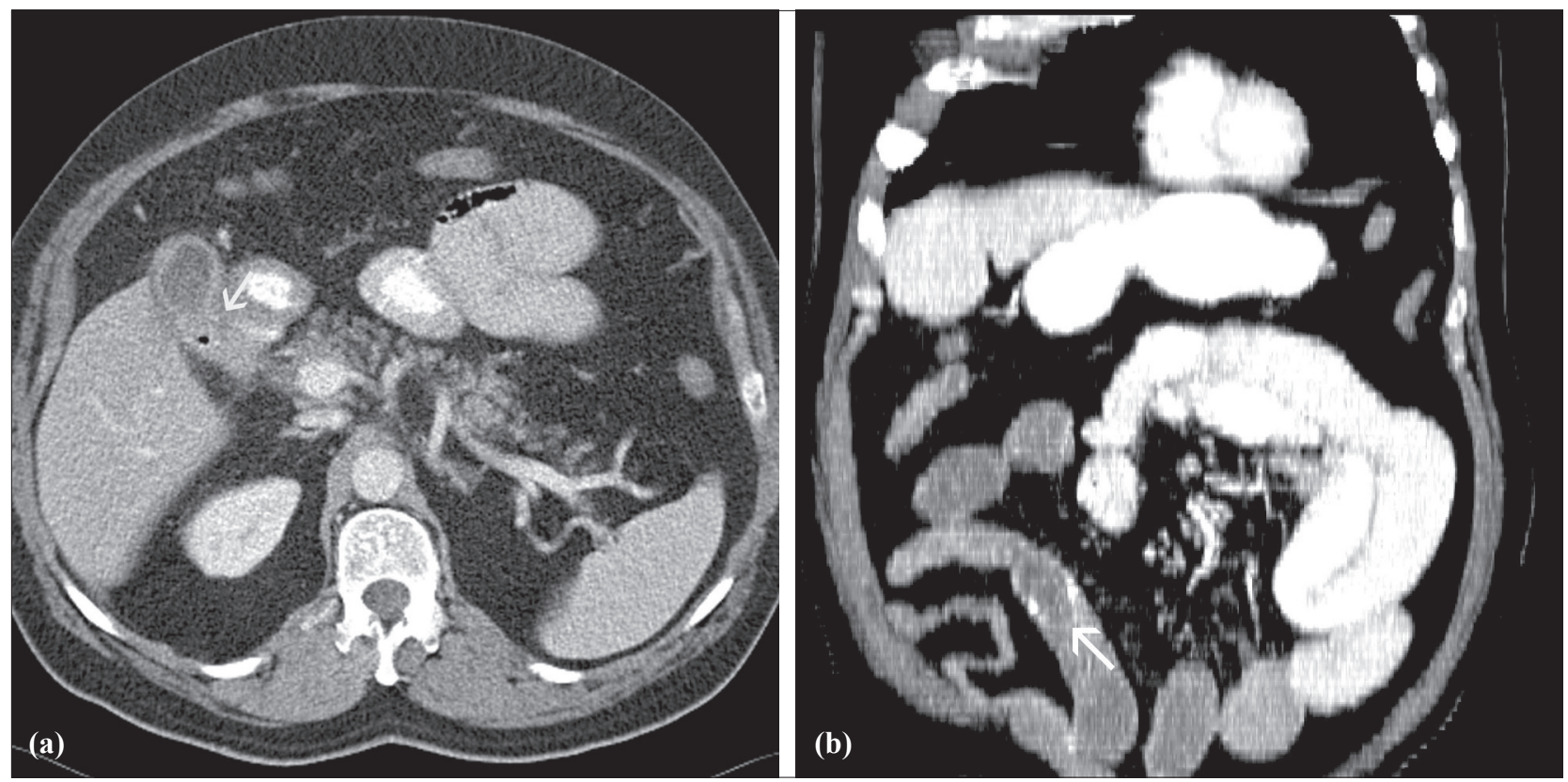

Fig. 1. (a) Axial CT shows a cholecystoduodenal fistula with evidence of gas in the gallbladder (arrow). (b) Volume-rendered coronal CT images show the gallstone impacted in the distal ileum (arrow) and dilated loops of the small bowel.

hancing wall that appeared to communicate with the dilated stomach and a large stone in the pyloric antrum (Fig. 2).

The diagnosis of Bouveret syndrome and cholecystitis was made, and he underwent an emergent laparotomy. During surgery, a cholecystogastric fistula was confirmed. Gastrotomy and extraction of the 4-cm gallstone, cholecystectomy and repair of the cholecystogastric fistula were performed.
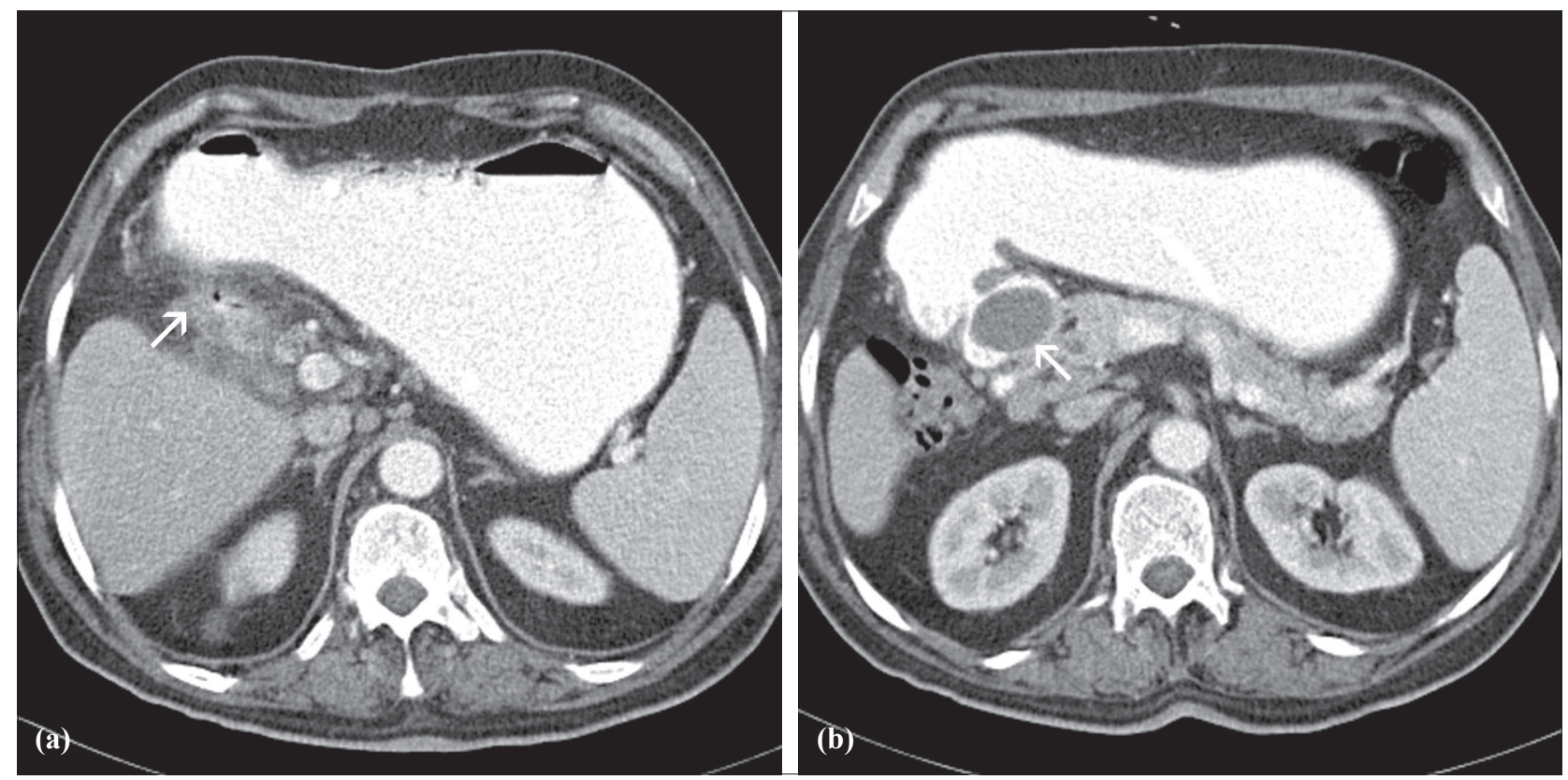

Fig. 2. (a) Axial CT images showing a cholecystogastric fistula. The gallbladder is contracted and contains gas and oral contrast material (arrow). (b) CT shows the gallstone impacted in the pylorus (arrow) and a very distended stomach. 
gallstone is called Bouveret syndrome, and is a rare complication of a biliodigestive fistula, where a large stone occludes the pyloroduodenal region. ${ }^{[1,2]}$ Antropyloric gallstones, a variant of Bouveret syndrome, are a very rare cause of gastric outlet obstruction. ${ }^{[6]}$

The mortality rate is between 12 and $27 \%$, due to concomitant diseases and the delayed diagnosis. The average age of patients with this rare condition is 70 to 75 years, with a 5 to 1 female-to-male predominance. ${ }^{[7]}$ The presenting clinical situation is variable and nonspecific, but often includes nausea, vomiting and epigastric pain. ${ }^{[2,3,7]}$

The classic radiographic triad of small bowel obstruction, pneumobilia and an ectopic gallstone, as described by Rigler (1941), ${ }^{[7,8]}$ is specific for gallstone ileus. Unfortunately, this triad of findings is suggested in only $30-35 \%$ of abdominal plain radiographs in the reported cases. With the increased use of CT for acute abdominal diseases, bowel obstruction, air in the biliary tree and, above all, ectopic gallstones, such conditions are now demonstrated more easily. ${ }^{[7]}$

Pneumobilia can be classified as intrahepatic (gas within the intrahepatic bile ducts) or cholecystic (gas within the gallbladder). ${ }^{[9]}$ In our cases, the CT images showed intrahepatic pneumobilia in one patient, while cholecystic pneumobilia was identified in both patients.

Computed tomography (CT) allows a correct diagnosis of gallstone ileus with greater accuracy. The information obtained on $\mathrm{CT}$ is used to make a rapid diagnosis and aids in the decision of whether surgical or conservative treatment would be most effective. This approach may decrease the rather high morbidity and mortality seen in this disease. CT is also useful for estimating the size of an impacted gallstone, especially at the transition point between dilated and collapsed bowel. ${ }^{[9]}$ In our cases, CT showed a cholecystoduodenal or cholecystogastric fistula and the transition point between the dilated and collapsed bowel. MDCT pro- vides an early, accurate diagnosis of gallstone ileus, enabling surgical treatment, as in our cases. The treatment of gallstone ileus requires an emergency laparotomy, removal of the impacted stone, cholecystectomy, and a fistula repair. ${ }^{[7]}$

In conclusion, gallstone-induced ileus is a rare complication of cholelithiasis, and gastric outlet obstruction is an even rarer variant that requires a rapid diagnosis and treatment. With the increased use of CT for patients presenting with acute abdomen and in view of its superiority over abdominal plain radiographs, radiologists should be aware of Rigler's triad for the diagnosis of gallstone ileus on CT. Early diagnosis and treatment may decrease the high mortality encountered in this disease.

\section{REFERENCES}

1. Brennan GB, Rosenberg RD, Arora S. Bouveret syndrome. Radiographics 2004;24:1171-5.

2. Chou JW, Hsu CH, Liao KF, Lai HC, Cheng KS, Peng CY, et al. Gallstone ileus: report of two cases and review of the literature. World J Gastroenterol 2007;13:1295-8.

3. Ji JS, Zhang SZ, Shao CX, Zhao ZW, Wang ZF, Lü GJ, et al. Imaging diagnosis of two unusual forms of gallstone ileus. Chin Med J (Engl) 2007;120:938-40.

4. Matur R, Yucel T, Gurdal SO, Akpinar A. Bouveret's syndrome: gastric outlet obstruction by a gallstone. Ulus Travma Derg 2002;8:179-82. [Article in Turkish]

5. Masannat YA, Caplin S, Brown T. A rare complication of a common disease: Bouveret syndrome, a case report. World J Gastroenterol 2006;12:2620-1.

6. Astolfi A, De Berardinis O, Lalli T, Del Cimmiuo P, Saragani C, Colecchia G. Antropyloric lithiasic obstruction: a variant of Bouveret's syndrome. Minerva Chir 1996;51:347-50. [Abstract]

7. Delabrousse E, Bartholomot B, Sohm O, Wallerand H, Kastler B. Gallstone ileus: CT findings. Eur Radiol 2000;10:938-40.

8. Gürleyik G, Gürleyik E. Gallstone ileus: demographic and clinical criteria supporting preoperative diagnosis. Ulus Travma Derg 2001;7:32-4.

9. Reimann AJ, Yeh BM, Breiman RS, Joe BN, Qayyum A, Coakley FV. Atypical cases of gallstone ileus evaluated with multidetector computed tomography. J Comput Assist Tomogr 2004;28:523-7. 